\title{
RIMA DALAM CERITA PANTUN BUDAK MANDJOR SEBAGAI BAHAN PEMBELAJARAN APRESIASI SASTRA DI SMA
}

\author{
Erna Ervilyana Rulita \\ MGMP Bahasa Sunda Kabupaten Garut \\ Pos-el: erna.ervilyana@gmail.com
}

\begin{abstract}
ABSTRAK
Penelitian ini bertujuan untuk mendeskripsikan jenis dan pola rima yang terdapat dalam cerita pantun serta implikasinya untuk bahan pembelajaran apresiasi sastra di SMA. Metode deskrptif digunakan dalam penelitian ini, data diolah dengan menggunakan tekhnik telaah pustaka. Data rima yang diperoleh dari cerita pantun Budak Mandjor yang dipantunkan oleh Ki Atjeng Tamadipura (Situraja - Sumedang) sejumlah 582 rima dengan frekuensi 1.182 kali. Hasil penelitian ini ditemukan 11 jenis rima yang meliputi purwakanti pangluyu, purwakanti maduswara, purwakanti mindoan kawit, purwakanti laras madya, purwakanti cakraswara, purwakanti rangkepan, purwakanti laras wekas, purwakanti mindoan wekas, purwakanti margaluyu, purwakanti laras purwa, purwakanti mindoan kata. Jenis rima yang paling dominan adalah purwakanti pangluyu yang berjumlah 125 dengan frekuensi sebanyak 246 kali (20,81\%). Sedangkan pola yang ditemukan dari setiap jenis rima tersebut merupakan pola struktur bahasa yang meliputi konsonan, vokal, suku kata, kata dan frasa. Hasil penelitian ini direkomendasikan untuk bahan pembelajaran aprésiasi sastra di SMA kelas XII.
\end{abstract}

Kata Kunci: rima, cerita pantun, bahan pembelajaran

\section{RHYMING OF BUDAK MANDJOR PANTUN AS A LITERATURE APPRECIATION TEACHING AND LEARNING MATERIAL IN SENIOR HIGH SCHOOL}

\begin{abstract}
This study aimed to describe the types and patterns of rhymes contained in pantun story and their implications for literature appreciation teaching and learning materials in senior high school. This study employed descriptive method, and its data were processed by literature review techniques. The data of rhyme obtained from the story of the Budak Mandjor pantun story sung by Ki Atjeng Tamadipura (Situraja - Sumedang) of total 582 rhymes with a frequency of 1.182 times. This study found 11 types of rhymes which included purwakanti pangluyu, purwakanti maduswara, purwakanti mindoan kawit, purwakanti laras madya, purwakanti cakraswara, purwakanti rangkepan, purwakanti laras wekas, purwakanti mindoan wekas, purwakanti margaluyu, purwakanti laras purwa, purwakanti mindoan kata. The most dominant type of rhyme is purwakanti pangluyu, which totaled 125 and its frequency is 246 times (20.81\%). While the pattern type found in each rhyme is a language structure pattern that includes consonants, vowels, syllables, words and phrases. The results of this study are recommended for literary teachinglearning materials in Grade XII Senior High School.
\end{abstract}

Keywords: rhyme, pantun story, learning material 


\section{PENDAHULUAN}

Dalam kehidupan sehari-hari masyarakat tidak pernah lepas dari proses komunikasi bahasa, begitu juga dengan masyarakat Sunda. Sebagai alat komunikasi, bahasa dipakai untuk menuangkan pikiran, kehendak, pendapat, gagasan, atau ide dari pembicara, baik secara lisan atau secara tulisan. Pikiran, kehendak, gagasan, atau ide bisa berwujud dalam bentuk karangan, seperti: dongeng, cerpen, novel, puisi, cerita pantun, dan wawacan.

Bahasa merupakan salah satu unsur penting dalam sebuah karya sastra, karena bahasa merupakan bahan, alat, dan sarana yang mengandung nilai untuk mewujudkan suatu karya. Selain itu, bahasa dalam karya sastra mempunyai fungsi sebagai unsur keindahan, hal ini merupakan aspek dari estetika.

Estetika bahasa dalam karya sastra bisa ditemukan dalam penggunaan purwakanti, begitu pula dalam cerita pantun.

Menurut Sulastri $(2015,63)$ dalam karya sastra Jawa, macapat bisa dinilai sifat estetisnya melewati purwakanti.

Faktanya, masyarakat sekarang sudah jarang yang tahu mengenai purwkanti. Begitu juga dengan materi pembelajaran yang sudah jarang membahas apresiasi sastra mengenai purwakanti. Padahal mempelajari purwakanti dalam sastra Sunda adalah bentuk dari upaya melestarikan khazanah bahasa dan sastra Sunda.

Menurut Iskandarwasid (2003, hal.121) purwakanti merupakan kedekatan suara atau kata-kata dalam susunan kalimat, klausa, atau frasa, terutama dalam bentuk puisi; baik yang berdekatan, sejajar horizontal (dalam satu kalimat, satu jajar, satu baris) atau berurutan, vertical (antarjajaran antarbaris). Senada dengan Iskandarwasid, Rusyana (1970, hal.15) menjelaskan bahwa purwakanti merupakan rima dalam dua suku kata atau lebih dalam kata yang berbeda. Rima itu baik vokal baik konsonan. Wibowo (TT, hal.35) menjelaskan bahwa dalam sastra Jawa istilah purwakanti dikenal oleh sebutan purwakanthi. Sedangkan dalam kepustakaan Indonesia dikenal dengan sebutan ritme atau rima (rhytm and rime).

Menurut Ruhaliah (2015, hal.42) teks sastra klasik termasuk cerita pantun, umumnya tersebar dalam media lisan serta bentuknya berupa puisi. Begitupun dengan Isnendes (2010, hal.56) yang menjelaskan bahwa cerita pantun merupakan puisi Sunda buhun yang berwujud cerita artinya dalam bentuk puisi tapi isinya berupa cerita.

Sebagai bentuk puisi, cerita pantun tentunya mempunyai struktur yang sama dengan karya sastra bentuk aturan lainnya. Waluyo (dalam Isnainiyah, 2015, hal.118) menjelaskan bahwa struktur puisi terbagi menjadi dua, yaitu struktur lahir (fisik) dan struktur batin. Struktur lahir (fisik) terdiri dari diksi, imaji, kata konkret, majas, verifikasi, dan tipografi, sedangkan struktur batin terdiri dari tema, rasa, dan amanat yang isinya berupa cerita. Dengan kata lain analisis purwakanti termasuk ke dalam analisis yang menggunakan struktur lahir (surface structure) bahasa sebagai objek penelitian.

Menurut Salmun (1960, hal. 25) purwakanti dalam sastra Sunda awalnya terbagi menjadi tiga jenis yaitu purwakanti-wiandjana berdasarkan wianjana (konsonan), purwakanti-swara berdasarkan, dan purwakanti-sastra, contohnya: paksa-pirusa, bérés roes, naktak-mundak, cageur-bageur, dan sajabana. Ini artinya pola struktur purwakanti dibentuk oleh konsonan, vokal, suku kata, kata, dan frase.

Berdasarkan pada latar belakang di atas, penelitian ini mempunyai tujuan untuk mendeskripsikan jenis dan pola rima dalam cerita pantun yaitu Carita Pantun Budak Mandjor (CPBM) serta 
implikasinya hasil penelitian sebagai bahan pembelajaran apresiasi sastra di SMA kelas XII.

\section{METODE}

Metode yang digunakan dalam penelitian ini adalah metode deskriptif. Menurut Djajasudarma (2010 hal.9) metode penelitian deskriptif merupakan metode yang mempunyai tujuan untuk membuat deskripsi; maksudnya membuat gambaran, rancangan yang sistematis, faktual, dan akurat mengenai data, sipatsipat serta hubungannya dengan fenomena-fenomena yang diteliti.

Metode deskriptif dalam penelitian ini yaitu untuk mendeskripsikan data purwakanti dan jenisnya yang terdapat CPBM serta implikasinya untuk bahan pembelajaran apresiasi sastra di SMA. Objek penelitian yang digunakan adalah teks tunggal, maksudnya yaitu teks yang dijadikan bahan penelitian hanya satu judul.

Tekhnik penelitian dibagi menjadi dua bagian yaitu tehnik pengumpulan data dan tehnik mengolah data. Tekhnik yang digunakan untuk mengumpulkan data yaitu tehnik studi pustaka, sedangkan tehnik yang dipakai dalam mengolah data yaitu deskriptif. Data dianalisis serta dilaporkan secara deskriptif dalam bentuk tulisan ilmiah.

\section{HASIL DAN PEMBAHASAN}

Hasil dari penelitian ini meliputi temuan mengenai jenis dan pola rima dalam CPBM serta implikasinya sebagai bahan ajar apresiasi sastra di SMA.

\section{Jenis dan Pola Rima dalam CPBM}

Dari hasil analisis data diperoleh 582 bentuk rima dengan frekuensi 1.182 kali. Kemudian data tersebut dibagi lagi berdasarkan jenis rima yang dijabarkan oleh Salmun (1960, kc. 34) yang mencakup purwakanti pangluyu, maduswara, cakraswara, laras purwa, laras madya, laras wekas, mindoan kawit, mindoan wekas, mindoan kata, dan margaluyu.

Dalam penelitian Carita Pantun Budak Mandjor (CPBM) ditemukan sejumlah data purwakanti yang tidak tergolong ke dalam jenis apapun. Faktor penyebabnya adalah data tersebut memiliki dua atau lebih ciri rima, utamanya dilihat dari tempat di mana ciri tersebut berada. Oleh karena itu, data tersebut oleh peneliti diberi nama purwakanti rangkepan. Jadi, seluruh jumlah jenis rima yang ditemukan ada 11 .

Dari 11 jenis rima ini masing-masing jenis-jenisnya mempunyai pola struktur bahasa yang meliputi konsonan, vokal, suku kata, kata, dan frasa.

Menurut Sudaryat spk, (2011, hal.21) konsonan dalam bahasa Sunda ada 18 yaitu: /b/, /c/, /d/, /g/, /h/, /j/, /k/, /l/, /m/, /n/, /ny/, /ng/, /p/, /r/, /s/, /t/, /w/, dan /y/. sedangkan aksara swara (vokal) ada 7 , yaitu /a/, /i/, /u/, lé/, /o/, /e/, dan /eu/.

Dilihat dari jenis kata struktur bahasa Sunda terbagi menjadi dua bagian yaitu kata baku dan kata tugas. Kata terbagi lagi menjadi empat macam yaitu kata benda (nomina), kata kerja (verba), kata sifat (adjektiva), dan kata bilangan (numeralia). Sedangkan partikel terbagi menjadi empat bagian, yaitu adverbial, konjungsi, préposisi dan interjeksi.

\section{Purwakanti Pangluyu}

Berdasarkan hasil penelitian, diperoleh 125 data purwakanti pangluyu dengan frekuensi 226 kali (20,81\%). Purwakanti pangluyu adalah rima yang mengacu pada satu susunan atau satu baris, bukan rima antarsusunan atau antarbaris. Jadi merupakan ranyatan. Disebut pangluyu karena rima ini menyesuaikan bunyi atau konsonan dalam kata-kata. Sekali lagi bunyi bukan vokal (Salmun, 1960, kc. 34)

Dari 125 data yang ditemukan ada 14 pola purwakanti pangluyu yang meliputi bunyi konsonan nasal-vélar /ng/ jumlahnya 64 , konsonan stop-vélar /-k-/ jumlahnya 13, konsonan stop-déntal /-t-/ 
dan bunyi /ah/ masing-masing jumlahnya 9, bunyi konsonan dan vokal campuran jumlahnya 9, konsonan trill-alvéolar /-r-/ jumlahnya 6 , bunyi pertukaran vokal jumlahnya 4, konsonan lateral-alvéolar /$l-/$ jumlahnya 3, konsonan frikatifalvéolar /-s-/ dan konsonan stop-bilabial /-p-/ masing-masing jumlahnya 2, serta bunyi /reum/, /pun/, /reun/ dan /ti/ masing-masing jumlahnya 1 . Contoh datanya seperti di bawah ini.

(1) ti tengah canembrang hérang

(CPBM/4/16/53)

\section{(2) kék kerewek baju bekék mani sakepék}

(CPBM/12/55/200)

\section{(3) kagurat ku hikayat digurit, tuluy dianggit}

(CPBM/7/34/136)

Dari contoh di atas terlihat ada penyesuaian bunyi dari setiap katanya. Pada data (1) ada penyesuaian bunyi /rang/ yaitu pada kata canembrang dan hérang. Pada data (2) ada penyesuaian bunti lék/ yaitu pada kata kék, kerwek, bekék, dan sakapék. Sedangkan pada data (3) penyesuaian bunyi terdapat pada kata kagurat dan hikayat, yaitu bunyi /at/, dan kata digurit dan dianggit yaitu bunyi /it/.

\section{Purwakanti Maduswara}

Berdasarkan hasil penelitian, diperoleh 66 data purwakanti maduswara dengan frekuensi 211 kali (17,85\%). Purwakanti maduswara mengacu pada suara vokal yang menjadi nilai keindahannya (Salmun, 1960, kc. 35).

Dalam sastra Jawa purwakanti maduswara atau asonansi ini dikenal dengan sebutan purwakhanti swara, yaitu rima persamaan suara vokal (Padmosoekotjo dina Wibowo, TT, kc. 35).

Dari 66 data yang ditemukan ada 21 pola purwakanti maduswara yang meliputi pola vokal $/ u+a /$ jumlahnya ada 17 , vokal $/ i+a /$ jumlahnya ada 15 , vokal /a/, /i/ dan lél masing-masing jumlahnya ada 4 , vokal /o/ jumlahnya ada 3 , vokal $|a+u /| o+,a /, \mid e u+a /$ dan $/ e ́+a /$ masingmasing jumlahnya ada 2 , serta vokal $/ u$, /u+i/, /u+o/, /a+e/, /a+é/, /é +i/, /i+a+é/, $/ i+i+u+a /, \quad / i+u+a /, \quad / i+a+a /, \quad$ dan $/ u+a+i /$ masing-masing jumlahnya ada 1 . Contoh datanya seperti di bawah ini.

(4) sasawi jadi di cai

(CPBM1/9/11)

(5) manggih pamali, mendakan doraka

(CPBM/2/11/19)

(6) nyukcruk laku nu rahayu mapay pusaka nu bijaksana

(CPBM/4/17/67)

Dari contoh di atas terlihat ada permainan suara vokal yang menjadi keindahaan kalimatnya. Pada data (4) keindahan berpusat pada vokal /i/ yaitu pada kata sasawi, jadi, di, dan cai. Pada data (5) keindahan berpusat pada vokal /i/ yaitu pada kata manggih dan pamali, serta keindahan bunyi /a/ yaitu pada kata mendakan dan doraka. Sedangkan pada data (6) keindahan vokal terlihat pada kata nyukcruk, laku dan rahayu yaitu vokal $/ u /$, dan kata mapay, pusaka, dan bijaksana yaitu vokal /a/.

\section{Purwakanti Cakraswara}

Berdasarkan hasil penelitian, diperoleh 62 data purwakanti cakraswara dengan frekuensi 128 kali (10,83\%). Puwakanti cakraswara mengacu pada rima yang suara vokalnya saling bertukar tempat antar satu kata dengan kata yang lainnya dalam satu kalimat atau satu baris, baik tempatnya berdekatan ataupun tidak (Salmun, 1960, kc. 36).

Dari 62 data yang ditemukan ada 10 pola purwakanti cakraswara yang meliputi pola bertukar vokal $/ u-a /$ menjadi / $a-u /$ jumlahnya ada 16 , bertukar vokal / $a-u /$ menjadi / $u$-a/ jumlahnya ada 15, bertukar vokal /a-i/ menjadi /i-a/ jumlahnya ada 13 , bertukar vokal $/ i-a /$ menjadi /a-i/ jumlahnya ada 8 , bertukar vokal /eu-i/menjadi /i-eu/ jumlahnya ada 
3, bertukar vokal /i-eu/menjadi /eu-i/ dan la-él menjadi lé-al masing-masing jumlahna jumlahnya ada 2 , bertukar vokal $/ e-a /$ menjadi $/ a-e /, / i-u /$ menjadi $/ u-i /$, dan $/ i-u /$ menjadi $/ u-i /$ masingmasing jumlahnya ada 1 . Contoh datanya seperti di bawah ini.

(7) agungna ka sunan ambu

$(\mathrm{CPBM} / 3 / 15 / 34)$

(8) nu calik di sirah lebak

$(\mathrm{CPBM} / 3 / 15 / 45)$

(9) sima aing sima maung

$(\mathrm{CPBM} / 3 / 15 / 50)$

Dari contoh data di atas terlihat ada vokal yang saling bertukar tempat pada satu kata dengan kata yang lainnya, baik kata yang berdekatan ataupun tidak berdekatan. Pada data (7) vokal yang saling bertukar tempat terdapat pada kata sunan dan ambu yaitu vokal $/ u-a /$ menjadi $/ a-u /$. Pada data (8) vokal yang saling bertukar tempat terdapat pada kata calik dan sirah yaitu vokal /a-i/ menjadi /i-a/. Sedangkan apada data (9) vokal yang saling bertukar tempat terdapat pada kata sima dan aing yaitu vokal $/ i-a /$ menjadi /a-i/.

\section{Purwakanti Laras Purwa}

Berdasarkan hasil penelitian, diperoleh 13 data purwakanti laras purwa dengan frekuensi 32 kali (2,71\%). Purwakanti laras purwa mengacu pada rima pengulangan suku kata yang berada di di awal kata dalam susunan kalimat baik sejajar (rantayan) ataupun berurutan (runtuyan) (Salmun, 1960, kc. 37).

Dari 13 data yang ditemukan ada 7 pola purwakanti laras purwa yang meliputi pola imbuhan depan /di-/ dan /ka-/ secara berurutan masing-masing jumlahnya ada 3, imbuhan depan /di-/ secara berurutan dan berjajar masingmasing jumlahnya ada 2 , serta imbuhan depan /ka-/, /su-/, dan /nga-/ masingmasing jumlahnya ada 1 . Conto datana ébréh ieu di handap.Contoh datanya seperti di bawah ini.

\section{(10)diheuleutan ditampian}

(CPBM/2/12/24)

\section{(11) kateda, kasuhun, katarima}

(CPBM/58/251/630)

Dari contoh di atas terlihat ada pengluangan suku kata di awal kata baik secara berurutan ataupun berjajar. Pada data (10) pengulangan terdapat pada imbuhan depan /di-/ secara berurutan yaitu pada kata diheuleutan dan ditampian. Sedangkan pada data (11) pengulangan terdapat pada imbuhan depan $/ k a /$ seara berjajar yaitu pada kata kateda, kasuhun, dan katarima.

\section{Purwakanti Laras Madya}

Berdasarkan hasil penelitian, diperoleh 57 data purwakanti laras madya dengan frekuensi 153 kali (12,94\%). Purwakanti laras madya mengacu pada suku kata, kata, dan frasa yang terdapat di tengah-tengah susunan kata-kata, keduanya bisa berjajar atau berurutan (Salmun, 1960, kc. 42).

Dari 57 data yang ditemukan, purwaknati laras madya dalam CPBM merupakan rima yang berurutan dengan ciri rimanya ada dalam bentuk kata dan frasa.

Pola yang ditemukan dalam purwakanti laras madya ada 8 pola yang meliputi preposisi dengan jumlahnya ada 19, konjungsi dengan jumlahnya ada 14 , kata kerja jumlahnya ada 8, kata barang jumlahnya ada 6, frasa preposisi jumlahnya ada 5 , kata sipat jumlahnya ada 2, serta adverbial dan kata bilangan masing-masing jumlahnya ada 1 . Contoh datanya seperti di bawah ini.

(12) agungna ka kanjeng gusti rasulullah

jembarna ka kanjeng nabi adam ka kanjeng nabi sulaeman singgetna ka kanjeng nabi Muhammad 
(CPBM/1/10/15)

\section{(13) bakti neda agung disuhunkeun neda berekah}

(CPBM/2/13/29)

\section{(14) agungna ka sunan ambu jembarna ka bujangga séda}

(CPBM/3/15/35)

Dari contoh di atas terlihat ada pengulangan kata dan frasa dalam setiap baris. Pada data (12) ada pengulangan frasa $/ k a$ kanjeng/ di tengah-tengah kalimat dalam setiap baris. Pada data (13) ada pengulangan kata kerja /neda/ di tengah-tengah kalimat dalam setiap baris. Sedangkan pada data (14) ada pengulangan preposisi $/ \mathrm{ka} /$ di tengahtengah kalimat dalam setiap baris.

\section{Purwakanti Laras Wekas}

Berdasarkan hasil penelitian, diperoleh 52 data purwakanti laras wekas dengan frekuensi 76 kali (6,43\%). Purwakanti laras wekas mengacu pada pengulangan bunyi suku kata yang berada di akhir kata, baik secara sejajar atau pun berurutan (Salmun, 1960, kc. 40).

Dari 52 data yang ditemukan, terdapat 21 pola purwakanti laras wekas yang meliputi pola suku kata akhiran /-na/ jumlahnya ada 11, suku kata akhiran /-ng/ jumlahnya ada 7 , suku kata akhiran /-ah/ jumlahnya ada 6, laras wekas rima bersilang jumlahnya ada 3, suku kata akhiran /-ti/, /-duk/, dan /-is/ jumlahnya ada 2, serta suku kata akhiran /-ji/, /-il/, /wal, /-dé/, /-nyal, /-ril, /-et/, /-agé/, /-or/, /-ok/, /-duk/, /-dak/, /-ia/ dan laras wekas berjajar masing-masing jumlahnya ada 1 . Contoh datanya seperti di bawah ini.

\section{(15) lengkong laila ilaha ilallah muhammadurasulullah lailaha ilallah muhammadurasulullah}

(CPBM/1/2/2)

(16) bismillah dijieun nu mimiti malah mandar padang ati disa'ir badan ka gusti

$(\mathrm{CPBM} / 1 / 3 / 3)$

Dari contoh di atas terlihat ada suku kata akhir yang diulang dalam setiap baris. Pada data (15) terdapat suku kata akhiran /lah/ secara berurutan yaitu pada kata ilallah, muhammadurasulullah, ilallah, dan muhammadurasulullah. Sedangkan pada data (16) pengulangan terdapat pada suku kata akhiran /ti/ secara berurutan yaitu pada kata mimiti, ati, dan gusti.

Selain itu, dalam purwakanti laras wekas juga terdapat pola yang sejajar dan pola rima bersilang. Datanya seperti di bawah ini.

\section{(17) Kéna-kéna ka nu hina}

(CPBM/113/493/1097)

(18) aya lumut dina batu aya keuyeup di muara, di muara kudu emut kanu waktu di dunya sakadar ngumbara

(CPBM/75/332/754)

Data (17) merupakan data laras wekas sejajar, sebab pengulangan suku kata akhiran /na/ sejajar dalam satu baris atau satu kalimat. Sedangkan data (18) merupakan data pola rima bersilang yang ditemukan dalam CPBM, yaitu pengulangan suku kata akhiran /tu/ pada baris ke satu dan ketiga, dan suku kata akhiran /ral pada baris kedua dan keempat.

\section{Purwakanti Mindoan Kawit}

Berdasarkan hasil penelitian, diperoleh 102 data purwakanti mindoan kawit dengan frekuensi 183 kali $(15,48 \%)$. Purwakanti mindoan mengacu pada pengulangan kata di awal baris atau awal susunan kata, yang berurutan antarbaris (Salmun, 1960, kc. 38).

Dari 102 data yang ditemukan ada 12 pola purwakanti mindoan kawit yang meliputi adverbia jumlahnya ada 20, kata kerja jumlahnya ada 19, préposisi jumlahnya ada 18 , kata kerja jumlahnya ada 16, konjungsi jumlahnya ada 12 , 
interjéksi jumlahnya ada 6, frasa preposisi dan kata sipat masing-masing jumlahnya ada 3, kata bilangan dan mindoan kawit rima bersilang masingmasing jumlahnya ada 2 , serta frasa verba dan frasa bilangan masing-masing jumlahnya ada 1.

(19) manggih lutung mumuludan manggih oa keur ngado'a

(CPBM/50/215/571)

(20) lain patih pasisian

lain ménak pupulasan

lain raja jijiadan

lain radén terah kokodén

(CPBM/7/32/127)

\section{(21) ti kuta salaka \\ ti kuta pandak \\ ti kadu pandak}

(CPBM/44/180/505)

Dari contoh di atas terlihat ada pengulangan kata diawal kalimat dalam setiap baris. Pada kata (19) kata yang diulang adalah kata kerja /manggih/. Pada data (20) kata yang diulang adalah adverbial /lain/. Sedangkan pada data (21) kata yang diulang adalah preposisi $/ t i /$.

Selain itu, dalam purwakanti mindoan kawit juga terdapat pola rima bersilang. Datanya seperti di bawah ini.

(22) mipir bilik njasar lincar

néangan sarangka péstol

mipir birit njasar bujal

néangan sarangka éta

(CPBM/12/58/205)

Pada data (23) kata yang saling bersilang adalah kata /mipir/ pada baris ke satu dan ketiga, dan kata /néangan/ pada baris kedua dan keempat.

\section{Purwakanti Mindoan Wekas}

Berdasarkan hasil penelitian, diperoleh 29 data purwakanti mindoan wekas dengan frekuensi 33 kali (2,79\%). Menurut Salmun (1960, kc. 42) purwakanti mindoan wekas merupakan kebalikan dari purwakanti mindoan kawit yaitu pengulangan kata atau frasa di akhir susunan kalimat secara berurutan antarbaris.

Dari 29 data yang ditremukan ada 8 pola purwakanti mindoan wekas yang meliputi kata benda jumlahnya ada 17 , kata kerja dan frasa preposisi masingmasing jumlahnya ada 3 , adverbia jumlahnya ada 2, serta frasa nomina, frasa verba, kecap sipat, dan interjéksi masing-masing jumlahnya ada 1 . Contoh datanya seperti di bawah ini

(23) mugia tetep rahmat salam ka nabi alaihi salam

$(\mathrm{CPBM} / 1 / 3 / 5)$

\section{(24) tanapi narajang alas} palias narajang alas

(CPBM/4/17/63)

(25) na lahuta teuing kapalay téh nyai tempo lis urang sabudi akal heula, nyai

(CPBM/10/51/189)

(CPBM/10/51/189)

Dari contoh di atas terlihat ada kata akhir yang diulang antarbaris. Pada data (23) kata yang diulang adalah /salam/. Pada data (24) pengulangan berupa frasa verba yaitu /narajang alas/. Sedangkan pada data (25) kata yang diulang adalah kata benda /nyai/.

\section{Purwakanti Mindoan Kecap}

Berdasarkan hasil penelitian, diperoleh 2 data purwakanti mindoan kecap dengan frekuensi 2 kali $(0,17 \%)$. Purwakanti mindoan kecap mengacu pengulangan kata yang sama namun memiliki arti yang berbeda (Salmun, 1960, kc. 44). Contohnya di bawah ini.

(26) kocap tuang sadérék agan aci haralang atuh jorojoy kagungan kapalay palay tuang iwak lutung tujuh likur monyét salawé jaralang sawidak

(CPBM/10/49/182) 
(27) yén di nagara kuta tandingan aya nu geulis taya tandingan

(CPBM/36/154/419)

Dari contoh di atas terdapat pengulangan kata yang sama namun mempunyai arti yang berbeda. Dalam data (26) pengulangan yang sama terdapat pada kata /tuang/, kata /tuang/ pada konteks yang pertama mempunyai arti sebagai adverbia 'milik' (posesif), sedangkan kata /tuang/ yang kedua yaitu bahasa halusnya dari dahar (makan). Pada data (27) pengulangan yang sama terdapat pada kata /tandingan/. Kata /tandingan/ yang pertama mempunyai arti sebagai kata benda nama satu Negara yaitu kuta tandingan, sedangkan kata /tandingan/ yang kedua mempunyai arti acuan perbandingan, melihat konteks kalimat sebelumnya yaitu "aya nu geulis taya tandingan" (ada yang cantik tidak ada bandingannya).

\section{Purwakanti Margaluyu}

Berdasarkan hasil penelitian, diperoleh 23 data purwakanti margaluyu dengan frekuensi 32 kali (2,71\%). Purwakanti margaluyu mengacu pada kata-kata yang berada di akhir kalimat kemudian diulang diawal kalimat di baris selanjutnya. (Salmun, 1960, kc. 43)

Dari 23 data yang ditemukan ada 7 pola purwakanti margaluyu yang meliputi pola frasa nomina jumlahnya ada 8, kata benda dan kata kerja jumlahnya ada 5 , frasa sipat jumlahnya ada 2, serta kata bilangan, kata sipat dan frasa preposisi masing-masing jumlahnya ada 1. Contoh datanya seperti di bawah ini.

(28) munah awi katut beusi

beusi katut ari

ari wesi braja manusa

(CPBM/5/17/78)

(29) caturkeun ratu ti kidul

ratu ti kidul kami mah palias kéneh

(CPBM/6/31/119)

(30) cat unggah gék calik calik ngahurun balung ku tuur

(CPBM/36/151/409)

Dari contoh di atas terlihat ada kata di akhir kalimat yang diulang di awal baris selanjutnya. Pada data (28) kata yang diulang merupakan kata benda yaitu beusi dan ari/. Pada data (28) pengulangan berupa frasa nomina yaitu /ratu ti kidul/. Sedangkan pada data (29) kata yang diulang merupan kata kerja yaitu /calik/.

\section{Purwakanti Rangkepan}

Berdasarkan hasil penelitian, diperoleh 51 data purwakanti rangkepan dengan frekuensi 86 kali (7,28\%). Purwakanti rangkepan ditemukan ketika proses analisis data ada data yang memiliki dua atau lebih ciri rima, utamanya dilihat dari tempat di mana ciri tersebut berada.

Dari 48 data data yang ditemukan ada 6 pola purwakanti rangkepan meliputi purwakanti mindoan kawit + laras madya jumlahnya ada 39 , mindoan kawit + mindoan wekas jumlahnya ada 4 , mindoan kawit + laras madya + pangluyu jumlahnya ada 4, mindoan kawit + laras wekas + pangluyu jumlahnya 2, laras purwa + laras wekas jumlahnya ada 1, laras madya + pangluyu jumlahnya ada 1. Contoh datanya seperti di bawah ini.

(31) ka luhur ka sang rumuhun

$\boldsymbol{k a}$ handap $\boldsymbol{k a}$ sang batara

ka batara ka batari

ka batara ka naga raja

ka batari naga sugih

(CPBM/1/10/14)

(32) ka para sahabat anu opat ka para malaikat anu opat

(CPBM/1/10/16)

$$
\begin{aligned}
& \text { (33)pangrajahkeun } \\
& \text { pangmunahkeun } \\
& \text { pangnyinglarkeun }
\end{aligned}
$$


$(\mathrm{CPBM} / 3 / 15 / 43)$

Dari contoh di atas terlihat ada pengulangan kata di dua tempat. Pada data (31) kata yang diulangnya sama yaitu preposisi $/ \mathrm{ka} /$ yang ada di awal dan di tengah kalimat antarbaris. Jadi data (31) merupakan purwakanti mindoan kawit + purwakanti laras madya. Pada data (32) pengulangan berupa frasa yaitu /ka para/ frasa preposisi si awal kalimat antarbaris dan frasa bilangan /anu opat/ di akhir kalimat antarbaris. Jadi data (32) merupakan purwakanti mindoan kawit + purwakanti mindoan wekas. Sedangkan pada data (33) pengulangan berupa suku kata imbuhan awal /pang/ pada setiap awal kata antarbaris dan imbuhan akhir /keun/ pada setiap akhir kata antar baris. Jadi data (33) merupakan purwakanti laras purwa + purwakanti laras wekas.

\section{Bahan Pembelajaran Di SMA Kelas XII}

Purwakanti dalam cerita pantun Budak Mandjor bisa dipakai sebagai bahan pembelajaran apresiasi sastra di SMA. Hal ini mengacu pada Kompetensi Inti dan Kompetensi Dasar (KIKD) Mata Pelajaran Bahasa dan Sastra berbasis kurikulum 2013, kedudukan apresiasi sastra carita pantun yang ada di SMA kelas XII, yaitu dalam KD "12.2.1Menunjukkan prilaku jujur, disiplin, peduli, dan santun, dan proaktif dalam menggunakan bahasa Sunda untuk mengaprésiasi wawacan dan carita pantun".

Pembelajaran apresiasi sastra carita pantun lebih memusatkan pada analisis struktur lahir (surface structure, agar siswa lebih memahami dan bisa menerapkan purwakanti sesuai dengan konteks kalimatnya.

Menurut Nasution (dalam Haerudin dan Kosim Kardana, 2013, kc. 77) pemilihan kriteria bahan pembelajaran yang baik meliputi:

1) bahan pembelajaran dipilih sesuai tujuan yang ingin dicapai;
2) bahan pembelajaran dipilih karena mempunyai nilai plus untuk bekal kehidupan;

3) bahan pembelajaran dipilih karena memiliki nilai sebagi warisan dari periode sebelumnya;

4) bahan pembelajaran dipilih agar memiliki pengetahuan dari satu bidang disiplin ilmu; dan

5) bahan pembelajaran dipilih dipilih berdasarkan kebutuhan peserta didik. Berdasarkan kriteria bahan pembelajaran yang dijabarkan di atas, bahan pembelajaran rima dalam CPBM bisa dikatakan baik. Hal ini dikarenakan, 1) langkanya bahan pembelajaran apresiasi sastra tentang rima, sehingga bahan pembelajaran ini sangat tepat untuk diaplikasikan; 2) bahan pembelajaran ini bisa meningkatkan keterampilan berbahasa peserta didik; 3) melalui pembelajaran tentang rima ini, peserta didik bisa meningkatkan kualitas dirinya, karena ilmu seseorang bisa tercermin dari bahasa yang ia gunakan; dan 4) melalui pembelajaran ini peserta didik dapat menambah perbendaharaan kata bahasa Sunda.

\section{SIMPULAN}

Berdasarkan hasil analisis dan deskripsi data yang telah dijelaskan sebelumnya mengenai purwakanti dan penerapannya dalam pembelajaran di SMA kelas XII dapat disimpulkan seperti di bawah ini.

Dalam penelitian CPBM diperoleh 582 data purwakanti, dengan frekuensi 1.182 kali. Data ini terbagi ke dalam 11 jenis purwakanti yang meliputi 125 purwakanti pangluyu dengan frekuensi 246 kali (20,81\%), 66 purwakanti maduswara dengan frekuensi ada 211 kali (17,85\%), 102 purwakanti mindoan kawit dengan frekuensi 183 kali (15,48\%). 57 purwakanti laras madya dengan frekuensi 153 kali (12,94\%), 62 purwakanti cakraswara dengan frekuensi 128 kali $(10,83 \%), 51$ purwakanti imbuhan dengan frekuensi 86 kali 
(7,28\%), 52 purwakanti laras wekas dengan frekuensi 76 kali (6,43\%) 29 purwakanti mindoan wekas dengan frekuensi 33 kali (2,79\%), 23 purwakanti margaluyu dengan frekuensi $32(2,71 \%)$, 13 purwakanti laras purwa dengan frekuensi 32 kali $(2,71 \%)$, dan 2 purwakanti margaluyu dengan frekuensi 2 kali $(0,17 \%)$.

Pola rima dari setiap jenis tersebut dibentuk oleh struktur bahasa yang meliputi konsonan, vokal, suku kata, kata dan frasa. Pola rima struktur konsonan lebih dominan dibangun oleh konsonan nasal-vélar $/ n g /$, stop-vélar /-k-/, stopdéntal / $t /$ / dan konsonan trill-alvéolar / $r-$ /. Pola rima struktur vokal lebih dominan dibangun oleh vokal $/ u /$, $/ a /$, jeung $/ i /$. Pola rima struktur kata lebih dominan dibangun oleh kata benda dan kata kerja. Pola rima struktur partikel lebih dominan dibangun oleh preposisi dan konjungsi.

Hasil penelitian baik digunakan sebagai bahan pembelajaran apresiasi sastra di SMA kelas XII.

\section{DAPTAR PUSTAKA}

Djajasudarma, T.F. (2010). Metode Linguistik: Ancangan Metode Penelitian dan Kajian. Bandung: PT. Refika Aditama

Haerudin, D jeung Kardana, K. (2013). Pengantar telaah buku ajar. Bandung: JPBD FPBS UPI.

Iskandarwassid. 2003. Kamus Istilah Sastra: Pangdeudeul Pangajaran Sastra Sunda. Bandung: Geger Sunten.

Isnainiyah, M. (2015). Struktur Fisik dan Struktur Batin Antologi Geguritan Kristal Emas Karya Suwardi Endraswara dan Rencana Pelaksanaan Pembelajaran di Kelas XI SMA, 6 (3) kc. 117-122. [Online]. Tersedia: http://download.portalgaruda.org/art cle.php?article [Sabtu, 25 Februari 2017].

Isnendes, R. (2010). Teori sastra. Bandung: DPBD FPBS UPS

Ruhaliah. (2015). Pendidikan Karakter dalam Sastra Sunda Klasik. Pendidikan Karakter dalam Budaya Sunda dan Jepang: Sebuah Kajian Perbandingan, 1 (1), kc. 4161.

Rusyana, Y. (1970) . Bagbagan Puisi Mantra Sunda. Bandung: Proyék Penelitian Pantun \& Folklore Sunda

Salmun, M.A. (1960). Kandaga Kasusastraan. Bandung: Ganaco.

Sudaryat, Y. (2011). Tata Basa Sunda Kiwari. Bandung. Yrama Widya

Sulastri, A. 2015. Kajian Etika dan Estetika dalam Serat Sangu Pati Jilid 2 Karya Ki Padma Sujana, 06 (01), kc. 61-69 [Online]. Tersedia: https://journal.usm.ac.id/jurnalhumaniora/article/view/1287. [Sabtu, 18 Maret 2017].

Wibowo, P.A.W. (TT). Kekhasan Purwakanthi dalam Empat Karya Sastra Ki Padmasusastra sebagai Cerminan Pandangan Hidup Masyarakat Jawa (Suatu Tinjauan Stilistika), kc. 33-43. [Online]. Tersedia: https://journal.usm.ac.id/jurnalhumaniora/article/view/1287. [Sabtu, 25 Februari 2017].

\section{UCAPAN TERIMA KASIH}

Penulis mengucapkan terima kasih kepada semua pihak yang telah membantu penelitian ini. Juga kepada jurnal Lokabasa saya ucapkan terima kasih atas penerbitan artikel ini. Semoga bermanfaat bagi masyarakat akademik. 